\title{
Conceptualizing the Implementation of Distance Learning System at the Higher Teacher's Training College of Maroua (Cameroon)
}

\author{
Emmanuel Béché, Ph.D. \\ Higher Teacher's Training College of the University of Maroua
}

\begin{abstract}
This article examined the implementation of an open and distance learning system at the Higher Teachers' Training College of Maroua. According to the perspective of Leclercq (2000), we described the components of this learning system based on its motives, objectives, principles, discourses, training programs and methodology, actors, target audience, structures, resources, ICTs used, challenges and perspectives. The analysis of these elements shows that beyond the intention to innovate and the efforts made regarding technological, human and financial resources, challenges remain at all the levels of the development of the project. However, the main perspective outlined here reveals that it is not necessary to have a "ready-to-wear" innovation or an imported one before implementing it in the African context.
\end{abstract}

Keywords: Implementation, distance learning system and Higher Teachers' Training College of Maroua.

\section{INTRODUCTION}

Like elsewhere in the world, advent of Internet in Cameroon in 1999 led to innovation in many areas of everyday life, such as society, economy, communication, politics, science, research, and education (Misse Misse, 2004). As Onguéné Essono and Onguéné Essono (2006) and Tchombé (2006) write, this innovation has resulted in important changes in production and diffusion methods of information. The domain of education is not immune to this trend. Besides, from a more global point of view, the adoption and the use of Information and Communication Technologies (ICT) in this context has provided substantial benefits in the field of training (Béché, 2013a). While scanning the desirable perspectives for African school, Fonkoua (2009) explains that it is impossible nowadays to reflect on the education and training without mention the use of ICT. If their use in education requires capacities and skills from teachers and learners (Béché, 2013b), Karsenti and Tchameni Ngami (2009) present their pedagogical integration around four major aspects: teaching with ICT, teaching through ICT, learning with ICT and learning through ICT. For Denis and Detroz (1999), open and distance learning (ODL) is what reflects the best these pillars.

Anderson and Dron (2011) define ODL as a system of teaching and learning characterized by four main properties. The first one is the separation of teachers and learners in time and/or place. The second refers to the use of multiple media in training. Thirdly, it involves two-way communication and occasional face-to-face meetings for tutorials and interactions. In a study on ODL in developing countries, Depover and Orivel (2012) expose their benefits regarding accessibility to education for African. As Fonkoua (2006) and Fournier Fall (2006) write, this training mode takes on positive contributions to the development of education in Africa. Besides Depover and Orivel (2012) characterize ODL as a free and flexible training mode. Students can thus access both online and locally to the learning resources. They also can choose training courses according to their rhythm and professional project, that is what Bob (1997) defines as a personalized or individualized training. By the same token, Karsenti and Collin (2011) argue that distance education is necessary both for students and educators in this region. In another paper, they explain that ODL is benefit in the way that they can contribute to training high qualified skills (Karsenti and Collin, 2011). They see it as an interesting alternative endowed with enormous potential. It can thus permit to deliver higher education by resolving triple constraints: expanding enrollment in universities, crippling budget cuts, and a soft labor market (Karsenti and Collin, 2013).

The ODL programs in Africa are mainly offered by Western universities, many local initiatives are also emerging as in Cameroon (Fonkoua and Béché, 2016). As Alter and Duveau-Patureau (2004) 
write, these new training projects can be described as an innovation. In fact, Zaltman, Duncan, and Hoelbek (1973, p. 10) define innovation as "any idea, practice, or material artifact perceived to be new by the relevant unit of adoption." In the field of education, De Landsheere (1970) specifies the term innovation as any transformation brought knowingly and systematically to an educational system, with the intention of revising its objectives or reaching better the assigned purpose in a more sustainable way. In a similar way, the OCDE (2005) defines it as the implementation of a product or a new or significantly improved process in the practices, relationships, and activities of a school system. The particularity of this explanation is to present the innovation as a process or a series of steps (Roger, 1995).

In Cameroon, the number of ODL projects has increased since 1995. They began as correspondence courses. Now, many are based on the use of ICT and internet. Besides, the orientation law of higher education of 2001 encourages them to commit themselves to this training mode. Its Article 11 specifies that "Distance learning is recognized and encouraged as an alternative mode of the development of higher education." So, as Béché and Fonkoua (2016) explain, despite the inadequacy of technology infrastructure, the deficit of local resources, and the absence of ICT development policy in school, more than twenty Cameroonian higher institutions involve in offering distance education. In the same way, they also mention that more than ten other universities are currently developing their ODL systems. Among this category, we have the Higher Teachers' Training College (HTTC) of the University of Maroua.

Created in 2008, this structure of the University of Maroua is involved in teachers training and is already making its way in the framework of distance education. Among the actions carried out to implement this innovation, we can mention the redesign of the training programs, the reflection on teaching procedures and approaches, and the development of the models of the learning activities management. These actions also concern the technological aspects, particularly with the design of a training mode where the use of ICT is firmly encouraged. As Anderson and Dron (2011) write, because it is done at a distance, the ODL system is based on the use of technological and digital to ensure the mediation of contents and interactions. It is in that way that the pedagogical integration of ICT constitutes on of its priority projects. Besides, it is present in all the managers' discourses as well as in teaching and learning practices. Furthermore, to increase its e-reputation and the relevant of its course offering, the managers encourage teachers and students to use ICT in their activities, despite the inadequacy of these technologies. The objective of this paper is to describe the beginning of the ODL project in that context. It thus focuses on the various actors and their roles, infrastructures, technologies, policies, implementation activities, and pedagogical practices. It emphasizes the main elements which characterize the first steps of an innovation such as the education at the HTTC of Maroua (Zaltman, Duncan and Hoelbek, 1973). We thus question the ways and strategies whereby this university implements its ODL project, by considering its beginnings.

Very often, it is after their design and implementation that the technological innovations in school begin to interest researchers (Tonye, 2011). In fact, most of the research analyze innovation when it is already built and designed. They consider it as a "ready-to-wear" object and aim to study its diffusion and adoption within a community for which it is destined (Rogers, 1995). In this approach, the object starts to be explored when it is already finalized and ready to be used by individuals and collectivities, which is close to the theory of diffusion (Rogers, 1995; Rogers and Floyd, 1995). However, as Millerand (1998) explains, the beginnings of an innovation are also interesting and play a determining role in its implementation and development. Furthermore, an innovation object is a dynamic social construction, which evolves as it gradually integrates the elements of the context its development. From this point of view, the first steps of an ODL project are as important as its utilization and diffusion. By emphasizing the emergence and development of the distance learning system at HTTC of Maroua, we examine the ingredients and actors which structure the evolution of that project. Our postulate is that the beginning of an ODL system plays a crucial role in its success or failure. Also, analyzing the traces of this techno-pedagogical innovation is full of lessons not only for its evolution but also for subsequent similar projects.

\section{The ODL At the HTtC of Maroua: Motivations, ObJectives, and Visions}

As any innovative project, the implementation of the ODL program at the HTTC of Maroua is based on motivations, objectives, and visions which are pedagogical, economic and structural (Hoegl and Gemuenden, 2001). In this institution, four main factors determine the foundation of the creation of 
that training mode: the university reform with the introduction of the Bachelor-Master-Doctorate (BMD) system, the professionalization of teaching, the infrastructural context, and the globalization of university education. As reflected in the law of higher education orientation, this university reform stresses on three elements related to distance education. The first two describe the ODL system and the use of the web technologies as essential tools necessary for the development of higher education in Cameroon. In other words, this law sees the university integration of ICT as a factor that makes Cameroonians universities capable of meeting the current and future challenges of the world of work and employment and contributes to the modernization of education. As we can see, this reform invites universities to promote the third generation of training. Although the term of "distance education" appears only twice in the law of higher education orientation, ODL is nevertheless valued and situated in the perspective of higher education development. Hence the "one student one laptop" program announced for September 2017.

While the "e-higher education network" project is being set up, the HTTC of Maroua intends to focus on the use of e-learning technologies to adapt to the new generation training opportunities (Kinuthia and Stewart, 2010). In the same way, the institution's academic policy and the discourses of its managers devote considerable attention to the implementation of the ODL system. They aim thus to modernize and ensure the international openness of their training opportunities while promoting the institution's inclusion in the Society of information (Castells, 2000). They argue that the development of the distance education program increases the e-reputation of the institution as well as its accessibility to a vast and diverse audience. In this university context, open and distance training is considered as an important instrument to make its educational system more opened and flexible, which is in line with its definition (Bozkurt and al., 2015). Through it, the institution envisages to revolutionize or even review its pedagogical and supervision practices, by taking advantage of the technological tools and the Internet to the benefit of the quality and professionalization of teachings. This goes through the implementation of the new training systems, which are innovative, open to its environment and attentive to the needs of individuals and societies.

In addition to this objective of revolutionizing pedagogy, the HTTC of Maroua also builds on the infrastructure revolution. In fact, as a young university institution, it is faced with major challenges regarding available infrastructure, while the student population is growing considerably and new training programs are being developed. The two questions the managers of the HTTC of Maroua always have are: how to meet the educational needs of students when the infrastructure capacity is not suitable to accommodate increasing student enrollment? How to provide higher education to professional workers who which to enhance their careers? Besides, most of the distance learning programs that are being developed at the HTTC of Maroua are based on the answer to these questions. By including professional workers in the university system through the open and distance training, it tends to demonstrate that insufficient physical structures and geographical distance from the campus cannot be an obstacle to educational offerings and quality of learning. However, this diversification of the training programs and their audience is also accompanied by some socioeconomic considerations. Considering the policy of university financial autonomy in Cameroon, implementing ODL projects also means diversification and multiplication of financial entries (Marty, 2014). This aspect allows us to underline the industrial character of the ODL system in this context (Morin, 2003; Moore, 2012; Simonson, Smaldino, Albright and Zvacek, 2011). As Wallet (2007) explains, behind its pedagogical and educational appearances, there are working economic considerations and industrial principles which constitute its functioning. One of the elements that reflect here this orientation is that the costs of distance training programs (1000 USD) are higher than those of face-to-face mode (100 USD).

In line with the motivations above, the HTTC of Maroua has assigned eight main objectives to its ODL system. The first one concerns the diversification of training offerings, which allows delivering a catalog of various programs able to fulfill the diverse needs of individuals and societies regarding abilities to develop. Besides, the programs of educational system audit, ICT for teaching and learning, digital pedagogy, and Peace-Security are part of this objective. The second objective linked to ODL is to compensate for the low infrastructure capacity which does not accommodate the increasing number of students. This is one of the reasons why continuing education programs are based on new distance communication technologies (Moore, 2012; Aderinoye, and Ojokheta, 2004). Thirdly, the implementation of distance learning in this context also aims to increase the openness and availability of the university programs to professionals who wish to pursue their studies while working (Karsenti and 
Collin, 2012, 2013). Furthermore, it intends to make the institution be a part of the Information Society (Castells, 2000), and to ensure its e-reputation while contributing to the globalization of university education (Stewart, 2012). The fifth objective is to take advantage of the use of the web technologies in training, regarding teaching, professionalization, and digital pedagogy. That leads to the sixth objective which concerns the development of individuals and collectivities through a training mode in which teachers and learners are separated in both time and place. Additionally, the ODL project here attempts to enable people improving their lifelong learning through their personal actions related to the learning object and their professional perspectives. Finally, it aims to provide innovative training whose flexibility, openness, and accessibility allow professional students remaining productive in their sector of activity. As we can see, these objectives combine pedagogical, social, political and economic dimensions of education and consider the challenges linked to the globalization of education (Anderson and Dron, 2011). They are not thus purely pedagogical: the ODL program itself result from the technological, social and economic concerns (Bozkurt and al., 2015). That is why the economic and infrastructure aspects are here more significant than those related to the quality of learning and skills.

\section{THE ACTORS OF THE INNOVATION}

As in any innovation (Charlier and Peraya, 2003; Denis and Vandeput, 2005), several actors contribute to the implementation of the ODL system at the HTTC of Maroua. We mean by actors all the people, services and technical systems that play a specific role in the development of this training mode (Lhomme and Fleury, 1999). We distinguish here five main actors, some of which intervene at the macro-sociological level and others at the micro-sociological level (Denis, 2003).

At the macro level, we have the managers of the school. Gibson (2002), Isabelle, Lapointe, and Chiasson (2002), and Otto and Albion (2002) emphasize the crucial role of school leaders in the implementation and the development of educational innovation. They argue that their leadership, discourses, and attitudes are one of the key factors of the successful integration of ICT into educational practices. In this perspective, ODL projects at the HTTC of Maroua have being initiated from the top, which is perceptible in its institutional development policy. This policy indicates that the distance training must start with continuing education programs and gradually extended to all others fields. The idea of setting up an ODL system came thus from the school managers. They are the ones who have revealed the need to meet the challenges regarding the diversification of training offerings, the democratization of higher education, the quality of learning, and the e-reputation within the information society. Their discourses and policies stress the use of the web technologies in educational practices, the digitalization of the pedagogical contents, the hybrid aspect of continuing education, and the accessibility of education to a vast and various audiences. By the same token, they encourage teachers and learners to integrate ICT in their university practices, which is pedagogically advantageous. To this effect, Larose and al. (2002) say that when the discourses and attitudes of school leaders are receptive to ICT, it encourages teachers and learners transferring and developing informatic skills in a university context. Besides, the managers of the HTTC of Maroua take some concrete actions both in their personal capacity and on behalf of the institution, which motivates lecturers to integrate technologies into their teaching practices (Béché, 2013). Among these actions, we can mention the opportunities provided for teachers to acquire technological tools, the subscription to online didactic resources, and technology training.

Besides the school management, the Division of Continuing and Distance Education is another macro-actor involved in the implementation of the ODL project at the HTTC of Maroua. It has two sub-structures including continuing education and distance learning. The aim of these two services is to promote the lifelong training of teachers and other professionals through the capacity building. To meet this challenge, they are the ones who have designed the ODL project regarding programs, process, activities, facilities, constraints, inputs, and outputs. They are therefore the major Department conducting this innovative project. For the last two years, for example, they have been training teachers to design, develop and use online courses. Two training sessions were thus organized, one from 14 to 16 May 2014 and the second from 10 to 13 June 2016. These courses to which all teachers and leaders of the HTTC of Maroua participated, have allowed them to strengthen their ability to use e-learning technologies. At the end of these training activities, many teachers have committed to integrating distance communication technology in their courses. In addition to ICT training, the Division of Continuing and Distance Education have also identified about ten training programs to be included in the ODL project. These programs are all professional or of lifelong learning. To this end, this Division makes available to all teachers, tools, supports and technological devices necessary to promote and deliver distance higher education. Through these actions, it provides technical and 
pedagogical support for capacity and skills building of teachers related to distance training. In brief, this Department is responsible for designing, organizing, managing, developing, and evaluating distance education system at the HTTC of Maroua. In this sense, it works out every year a development plan to enhance the ODL program, which places it at the center of this innovation system. Hence its partnership with the Agence Universitaire de la Francophonie known for its involvement in the implementation and development of most ODL systems in French-speaking Africa (Karsenti and Collin, 2010).

This center depends directly on the school management. Its role is to provide technical, pedagogical and numerical support for the development of the ODL system. Being a component of this innovative process, it is like "the oil that drives the engine" of the ODL system. It, therefore, designs, manages, develops and evaluates the activities of training, development, information and technological watch related to ICT in education. To achieve this mission, the Center for Educational Technology Resources has defined five main fields of activities that contribute to the development of e-learning resources and practices within the institution. The first concerns the management of materials, the digital identification of students and the organization of training projects on ICT use. The second category of its activities relates to technological watch, creation and dissemination of information, and connectivity and networking. The third set of its activities is the management of the institution's website and the creation of a database which includes academic and pedagogical resources. The last two services relate respectively to the installation and maintenance of computer hardware and software, and to monitoring, printing, and reprographic tasks. All these activities provide users with techno-pedagogical and digital resources related to their training activities. As far as distance education is concerned, this center provides opportunities for developing technological skills and tutorials for learners and teachers in using distance technology. It thus has about a hundred computers connected to the Internet, accessible to students and teachers and used free in the context of training. In Cameroon, the HTTC of Maroua is the only university institution that offers its students and educators free access to technological and computer services. In addition to computer and Internet technology, the Center for Educational Technology Resources also has video-projection and videoconferencing tools and devices, which can be used to organize computer-assisted courses or conferences at a distance. It also offers its users opportunities to exploit online databases such as that of CAIRN and JSTOR. The Center for Educational Technology Resources is thus used to support distance education and to strengthen its hybrid dimension. As an e-learning center, it facilitates the cohorts of students and teachers and constitutes a framework of tutoring.

The fourth group of actors of the implementation of the ODL project at the HTTC of Maroua includes the Departments and their teachers. As Charlier and Denis (2002) write, teachers' contributions and actions are crucial in an innovative technological project in education. Depover (1999) also shows that in this process it is the teacher who plays the leading role; it is he who can re-orientate the technology to meet its needs, for the benefit of the learners. For this author, the teacher remains the mainspring of the technological innovation in school, because he possesses an institutional and social recognition of the new practices that he is likely to put in place. He argues that the integration of ICT in schools passes through teachers. The school must, therefore, invest in them by taking advantage of the positive pressures of the technological environment. This perspective is also supported by Tchameni Ngamo (2007). He explains that for the pedagogical integration of ICTs to succeed, teachers should be given the opportunity to integrate these technologies. The HHTC of Maroua does not hesitate to undertake institutional initiatives designed to encourage teachers to use e-learning technologies and learning management systems. These initiatives are both financial and technical. At the economic level, the institution devotes an annual budget for training, internship, research, and development. Each year, it thus finances the participation of teachers in training courses on the use of ICT, most of which are organized by the Agence Universitaire de la Francophonie. The HTTC of Maroua also finances national and international training courses in several fields, including the ODL. Currently, three-quarters of teachers have attended at least one ICT training offered by this structure.

The objective of these initiatives is to build local resources necessary for the development of the elearning system, which, moreover, is lacking for most Cameroonian universities involved in the development of distance education. At the technical level, the HTTC of Maroua has equipped offices, departments and lecture rooms with computers and the Internet, which gives teachers the opportunity to benefit from the use new technologies. The Center for Educational Technology Resources is also open to teachers for the use of ICT, the computer-assisted courses, and the web conferences. These elements which are part of the institution's digital and pedagogical environment encourage distance learning practices. In addition to these institutional initiatives, there are also individual actions 
undertaken by teachers to integrate the use of ICTs in their teaching practices. All teachers thus have at least one laptop and a personal Internet connection. Similarly, all of them declare to have the necessary computer skills, which allows them to use a video projector, online storage devices, and digital broadcasting tools in their classes. Several of them also use open resources including learning management systems like Neolms.com and Edmodo.com in their teachings. By combining institutional and individual initiatives, teachers of the HTTC of Maroua can use ICT to design their lessons, evaluate the learning activities, and tutor their learners. They can also offer students specific educational supports that favor their autonomy (Marca, 2007). For the beginnings of its ODL system, the support emphasizes the technical aspects of the training, which allows learners to adapt to the chosen learning management system.

The last category of actors of the ODL project at the HTTC of Maroua includes technicians and experts. In fact, a distance education system is not only pedagogical. Being a part of the innovation, it is also contingent on technical and informatic aspects. As Moore (2012) writes, its implementation and functioning depend on ICT use and thus necessitate technological and strategic skills. To take account of this dimension, the HTTC of Maroua has a technical framework made up of technicians and computer specialists. They are a team consisting of two programmers, two electronic maintainers, one network expert, two designers and trainers, one learning management system administrator, and four technicians. Their role is to technically accompany the carrying out, the functioning, the use and the development of the distance learning system within the institution. In concrete terms, they design the ODL project scenario and facilitate its utilization. It is they who elaborate the abstract interface of the tool as well as its concrete interface also called the graphic chart; it is they who also design the navigation and communication scenario. These technicians and experts have the technical, methodological, procedural and organizational skills necessary to manage an ODL system and to fix any dysfunction of the learning management system or any other technological tool (Katz, 1974).

\section{Training Programs, Target Audience, and Resources}

Considering the institutional development policy of the HTTC of Maroua, two major steps intersperse the evolution of its ODL system. The first phase consisted of focusing the distance education system on the continuing education, research master, and professional doctorate programs. The second is to progressively generalize the distance learning system to all the training offerings, including initial and continuing education. This second stage allows to include in the ODL project the programs of bachelor, master, and doctorate. Among the training programs already taught at a distance, there are two university certificates. The first is in digital pedagogy and the second on peace and security issues. In this category of distance learning courses, there are also seven master's research programs: history and international relations, language and Arabic literature, regional security, geography, chemistry, physics sciences, and sciences of education. The latter is the most advanced program, with six specializations: educational planning and administration, didactics and learning assessment, educational system audit and inspection, specialized education, reform and reconstruction of school systems in crisis, and ICT applied to Teaching and learning. It is in this area of education that the professional doctoral program is also developed. Run by the Division of Continuing and Distance Education and the Academic Departments, these programs are more part of continuing and vocational training than of initial and academic one. Their target audience is also diverse and has the same characteristics as the users of the other ODL systems implemented elsewhere in French-speaking subSaharan Africa (Karsenti and Collin, 2012).

As we said, like the training programs offered by distance, their public is also diverse and vast. They are aimed at professionals and practitioners in some specific fields such as education, security, administration, jurisdiction, politics, and engineering. They are workers who, seeking to pursue their studies and improve their careers, engage in academic training. These categories of persons are the main users of the ODL systems in Africa (Karsenti and Collin, 2012). The distance programs at the HTTC of Maroua are also aimed at non-professionals with a required diploma. These are students who have obtained a bachelor's, master's, or equivalent degree in the field requested and for the level of study envisaged. The target audience for distance learning programs at the HTTC of Maroua is also open concerning their ages. There are young people and seniors, hence the emphasis on pedagogy and adult education as the methodological basis of training. The third characteristic of these distance training offerings regarding openness is their international scope. They are offered both to nationals and foreigners, most of whom are Chadians, Central Africans, Nigeriens, and Nigerians. 
As Denis (2001) explains, the implementation and the development of a distance learning system depend on the use of diverse resources. For Arinto (2016), these resources are political, administrative, technological, digital, material, financial and human. At the HTTC of Maroua, the administrative resources refer first to the leadership of it managers. As we said above, their attitudes, discourses, and actions are favorable to technological innovation in school. Even though the university institution is not provided with a development policy of the distance education system, its head encourages and stimulates teachers and learners to integrate distance communication technologies in their practices. Secondly, this type of resources includes also the existence of specialized structures in charge of the ODL conception, implementation, and management. Among them, we have the Division of Continuing and Distance Education, the Center for Educational Technology Resources, the Academic Departments, the Informatics cell, and the Division of Technological Development. As for technological and digital resources, they include about one hundred computers, internet connections, video-projection and video-conferencing tools, printing service, and copying office. In this category, we also mention the website of the institution which promotes its distance education programs, as well as its subscriptions to academic and pedagogical services online. The HTTC of Maroua is thus subscribed to CAIRN and JSTOR databases, enabling students and teachers to access rich and up-to-date documentary resources. It also subscribes to an anti-plagiarism software: "Unplag," which allows them to improve their academic and learning activities. Locally, the institution also has a Technology Watch newsletter. Produced by the Center for Educational Technology Resources, this bi-weekly newspaper is designed to disseminate to teachers and learners the latest developments on document, technological, pedagogical and digital resources. Finally, this Center also provides tutorials for the academic community, to explain how to use the Learning Management System, including educational materials and digital training content that can be accessed locally. From a financial perspective, the HTTC of Maroua devotes an important part of its budget to the development of training courses, particularly those at a distance. This funding concerns the hosting and delivering of the website, the design of the ODL system, the development of educational activities, and the acquisition of informatics tools and services. It also relates to the subscriptions to on-line computer services, the training internship of teachers, the organization of face-to-face modes, and the research facilities. The budgetary share allocated to these activities is one of the most important in the functioning of the institution. Finally, as far as human resources are concerned, they include teachers who are involved in the ODL system. More than $60 \%$ of them have received training or internship courses in the field of ICT in education. They are involved in the pedagogical design and management of the ODL system at the HTTC of Maroua, the organization of the tutorial system, teachings, and assessments. Amon these human resources, there are also technicians and informatic and technology specialists who deal with the technological aspects of the device and its technical components: platform, Internet connection, subscriptions to online services, computer software and hardware, maintenance and applications development.

For its beginnings in the development of distance education, the HTTC of Maroua has tested two learning management systems by using them in the context of learning. This approach means that while being tested, they are used as supports for the ODL system. Therefore, instead of using theoretical, and comparative studies or pilot experiments, this institution has opted for a development of the system as it is utilized in a real training context. It is an approach that is part of the sociology of translation (Akrich, Callon and Latour, 2006). It is thus the opposite of those used by most Cameroonian and even African universities involved in distance education (Karsenti and Collin, 2012). In the latter, the use of the ODL systems is always preceded by pilot experiments and characterized by the intervention of foreign actors and exogenous resources. The two learning management systems thus tested and used are Moodle and Neolms.com. Both are open sources, but the firs one requires a hosting service. If the second is entirely online, it also has an enterprise/paid option. Their choice was dictated by the consideration of three main elements: their widespread use in the French-speaking world, their availability and accessibility, and their ease of design and use (Giezendanner, 2008). Available online, Moodle and Neolms.com provide a learning environment for exchanges and interactions between learners and educators and accessibility to the curriculum content. They also offer a framework of thesocio-constructivist perspective of training by encouraging individualized and collaborative learning. In their pedagogical use, theemphasis is given to these learning elements: training content and learning activities design, teaching support, and tutorial. The objective is to take advantage of the technological environment offered by these learning management 
systems to enhance the quality of education and the skills development. Their use in the context of training is always preceded by digital literacy sessions, during which students learn how to use the platforms and other learning open sources. These courses aim to master the technical use of these platforms, to appropriate them and to integrate them into their training practices. They are thus useful in a context of the low level of technological development and at the beginning of the ODL system implementation. Once completed, they allow learners to focus on the content of their training without losing enough time on the technological aspects.

\section{Challenges and OpPortunities}

As Garrison (2009) writes, the adoption of a distance learning system is not static, nor should it be a fad phenomenon. On the contrary, it must be at the service of the quality of training, the development of skills and the accessibility to education. In this perspective, the implementation of the ODL project at the HTTC of Maroua presents many challenges and perspectives. The first ones are technical. As pointed out above, the use of an ODL system depends fundamentally on the technological and digital tools. Besides, their availability, accessibility, and usability are crucial to the success of this training mode. These technical challenges consist thus of improving the user-to-computer ratios, the computer performance, the quality of the Internet connection, and the acquisition of software and web services necessary for the development of distance training. As Karsenti and Collin $(2012,2013)$ explain, the acquisition, the availability and the technological accessibility determine the appropriation of ICT in distance education. These considerations invite a closer look at the improvement of the technological development index of the institution which requires the generalization of ICT, the availability of specialized structures, and the digital skills training. In Africa, most university organizations involved in providing distance education face lack of computer equipment (Karsenti and Collin, 2011). Despite the efforts made, the HTTC of Maroua is no exception. It is also confronted with the deficit of technological infrastructure, which is necessary for the implementation of the ODL program. This infrastructural or material challenge also results from to the financial problem. It does not yet have a financial partner to support its distance education program. The success of such project requires considerable funding. The second challenges and perspectives concern the pedagogical use of ICT. Technologically equipping the structures and actors involved in the ODL program is not enough if they are not used for their intended purpose, namely their use to provide distance education. As Depover (1999) argues, it is not just about introducing ICT and innovative tools in the classroom. The important thing is that these tools are pedagogically beneficial and serve the education and training. In this light, training in the pedagogical use of ICT in distance education is a perspective. Finally, these challenges and perspectives also relate to the techno-pedagogical training. As Denis (2003) shows, it includes the training of teachers, tutors, administrators and students. From the moment when the use of a distance training device requires various skills, i.e., disciplinary, technical, informatics, pedagogical, administrative, social, communication, and methodological, it is important to emphasis on training activities (Albero, 2003). In the context of the HTTC of Maroua, it consists of improving the existing training offerings and activities, for strengthening local resources and skills. As Depover and Orivel (2012), and Fonkoua and Béché (2016) write, one of the problems of Cameroonian universities, even African, about distance education concerns the inadequacy of local expertise.

\section{Conclusion}

In this article, we described the onset of the implementation of the ODL project at the HTTC of Maroua from a descriptive and exploratory perspective. As Zaltman, Duncan and Hoelbek (1973) show, the first steps of innovation are one of the factors that determine the future direction of its development and evolution. We then undertook to examine actions and actors that characterized the beginnings of the distance education system in this university institution, which, moreover, considers the ODL system as necessary to meet the new training challenges and opportunities.

We then focused our work on the main components of a training system (Leclercq, 2000). We have thus examined the motives, visions, objectives and principles that underlie and characterize the ODL system in this context. We also presented its actors, methodology and training programs, technological tools and services, target audience, and various resources. Finally, we described its constraints regarding the challenges to be achieved. The description of these elements shows that the implementation of the distance education program at the HTTC of Maroua is part of an approach close to the sociology of translation (Akrich, 1987). In fact, the design and development of the 
technological support of the training are done gradually by integrating the elements of the context. They are carried out in the training context.

If the efforts made should be highlighted, the development of the ODL system at the HTTC of Maroua nevertheless faces critical challenges, which are classic but fundamental. They relate to technological equipment, the accessibility of distance education, and the democratization of the Internet. The educational use of distance communication technologies and the IT teachers training are also important challenges. The same applies to the aspects related to financing, management, evaluation and development of the project, especially in a context where very often innovations once implemented no longer concern their designers or their users. The description of the beginnings of the FOAD at the HTTC of Maroua shows that it is not necessary to have a "ready-to-wear" innovation or an imported system before implementing it. It also demonstrates that the insufficient physical structures and the geographical distance from the campus cannot be an obstacle to educational offerings and quality of learning. In this perspective, these beginnings provide both the starting point and the gap to be filled to achieve the stability necessary for anchoring the project. Finally, they provide information on the development prospects of this system and the relevant of the first actions.

\section{REFERENCES}

Aderinoye, R. \&Ojokheta, K. (2004). Open-Distance Education as a Mechanism for Sustainable Development: Reflections on the Nigerian Experience. The International Review of Research in Open and Distributed Learning, 5(1), 1-13.

Akrich, M. (1987). Comment décrire les objets techniques? Techniques et Culture, 9, 49-64.

Albero, B. (2003). L'autoformation dans les dispositifs de formation ouverte et à distance: Instrumenter le développement de l'autonomie dans les apprentissages. In I. Saleh, D. Lepage et S. Bouyahi (dir.). (2003). Les TIC au cours de l'enseignement supérieure. Acte de la journée d'études. Laboratoire Paragraphe, Université Paris VIII-Vincennes-st Denis, 139-159.

Alter, N. (2001). L'innovation ordinaire. Paris: PUF.

Anderson, T., \&Dron, J. (2011). Three generations of distance education pedagogy. International review of research in open and distance learning, 12(3), 80-97.

Arinto, P. (2016). Issues and Challenges in Open and Distance e-Learning: Perspectives from the Philippines. International Review of Research in Open and Distributed, 17(2), 162-180.

Béché, E. \& Fonkoua, P. (2016). Introduction: Utility, usability and acceptability of open and distance learning in Cameroonian university context. In P. Fonkoua et E. Béché (dir.). Les formations ouvertes et à distance au Cameroun: Entre discours et réalités d'innovation (p. 11-32). Paris: L'Harmattan.

Béché, E. (2013a). Le rôle de l'usage de l'ordinateur dans le travail scolaire des apprenants : Opinions des élèves des lycées Général Leclerc et bilingue de Yaoundé (Cameroun). In C. Dili Palai et M. Etuge Apuge (dir.). Langages, Littérature et Éducation au Cameroun (p. 195-218).Paris: L'Harmattan.

Béché, E. (2013b). TIC et innovations dans les pratiques enseignantes au Cameroun. Frantice.net, 6, 5-21.

Bob Moon (1997). Open Learning and New Technologies in Teacher Education: New paradigms for development. European Journal of Teacher Education, 20(1), 7-31.

Bozkurt Aras \& al. (2015). Trends in Distance Education Research: A Content Analysis of Journals 2009-2013. International Review of Research in Open and Distributed Learning, 16(1), 330-363.

Castells, M. (2000). The rise of the network society. Oxford: Blackwell.

Charler, B.\&Peraya, D. (dir.). (2003). Technologie et innovation en pédagogie : Dispositifs innovants de formation pour l'enseignement supérieur. Bruxelles : De Boeck.

Charlier, B., \&Denis, B. (2002, mars). Form@HETICE : Un dispositif de formation continuée des formateurs d'enseignants à un usage critique des Technologies de l'Information et de la Communication. Communication présentée au 2e Congrès des chercheurs en Éducation. Bruxelles, répéré le 10 avril 2010 du site http://www.enseignement.be/ download.php? do _ id= 2265

Denis, B. (2003). Quels rôles et quelle formation pour les tuteurs intervenant dans des dispositifs de formation à distance? Distance et Savoir, 1(1), 19-46. 
Denis, B.\&Detroz, P. (1999). De l'utilité d'implanter les nouvelles technologies de l'information et de la communication (NTIC) dans l'enseignement à distance : IAD. Istruzione a Distanza,11, 46-72.

Denis, B.\&Vandeput, E. (2005). Une démarche innovante de formation à l'intégration des TICE dans la pratique des futurs enseignants du supérieur. Communication présentée au XXe colloque de l'AIPU. L'enseignement supérieur du XXIe siècle: De nouveaux défis à relever, Genève.

Depover, C. (1999). Le chemin de l'école croisera-t-il un jour celui des nouvelles technologies? In P. Bordeleau, C. Depover \&B. Noël (dir.). L'évaluation des compétences et des processus cognitifs : Modèles, pratiques et compétences (p. 284-302). Bruxelles : De Boeck.

Depover, C.\&Orivel, F. (2012). (dir). Les pays en développement à l'ère de l'e-learning. Paris: Unesco.

Duveau-Patureau, V. (2004). Accompagner le changement des organismes de formation par la FOAD. Distances et Savoirs, 2, 25-38.

Faouzia, M.\&Darhmaoui, H. (2012). FOAD: Défis d'une solution prometteuse pour la formation continue des enseignants. Frantice.net, 5,13-39.

Fluckiger, C. (2007). L'appropriation des TIC par les collégiens dans les sphères familières et scolaires (Thèse de Doctorat inédite). Département des Sciences de l'Éducation, ENS de Cahan.

Fonkoua, P. \& Béché E. (2016). Open and distance Learning in Cameroon: Discourses and realities of the innovation.Paris : L'Harmattan.

Fonkoua, P. (2006). Approche conceptuelle de la "Ticelogie" ou Science de l'intégration des TIC dans la formation des formateurs. In P. Fonkoua (dir.). Intégration des TIC dans le processus enseignement-apprentissage au Cameroun (p. 223-234). Yaoundé: Terroirs.

Fonkoua, P. (2009). Les TIC pour les enseignants d'aujourd'hui et de demain. In T. Karsenti (dir.). Intégration pédagogique des TIC en Afrique : Stratégies d'action et pistes de réflexion (p. 151181). Ottawa : CRDI.

Fontaine, P.\&Denis, B. (2008). Usages de l'ordinateur et apports des médias et des TIC en enseignement. Construction d'un curriculum de cours destiné aux futurs enseignants de la Communauté française de Belgique. Communication présentée au XXVe Colloque de l'Association Internationale de Pédagogie Universitaire (AIPU). Le Défi de la qualité dans l'enseignement supérieur : Vers un changement de paradigme, Montpellier.

Fournier Fall, A. (2006). Enseignement à distance supporté par les NTIC au Sénégal: Vers l'accession d'un public nouveau à l'enseignement supérieur? Étude empirique sur le profil des étudiants de l'enseignement à distance supporté par les NTIC au Sénégal (thèse de doctorat inédite), Faculté des lettres de l'Université de Fribourg, Suisse.

Garrison, R. (2009). Implications of online learning for the conceptual development and practice of distance education. Journal of Distance Education, 23(2), 93-104.

Gibson, I. W. (2001). The role of school administrators in the process of effectively integrating educational technology into school learning environments: New research from the Mid-West. In Technology is the catalyst. Communication présentée au 12ecolloque international de Society for Information Technology and Teacher Education. SITE, Orlando, FL.

Glikman, V. (2008, avril). Quels modèles d'exercice de la formation tutorale à distance pour quels types d'apprenants? Communication présentée au colloque euro-méditerranéen et africain d'approfondissement sur la formation à distance (cemaforad4), Strasbourg, France. Repéré le 18 mai 2015 du site http://edison.u-strasbg.fr/openconf/papers/84.pdf

Hoegl, M. \& Gemuenden, H. G. (2001). Teamwork Quality and the Success of Innovative Projects: A Theoretical Concept and Empirical Evidence. Organization Science, 12(4), 435-449.

Isabelle, C. lapointe, C.\&Chiasson, M. (2002). Pour une intégration réussie des TIC à l'école: De la formation des directions à la formation des maîtres. Revue des Sciences de l'Éducation, 28(2), 325-343.

Karsenti, T. (2009). Intégration pédagogique des TIC en Afrique : Stratégies d'action et pistes de réflexion. Ottawa : CRDI.

Karsenti, T.\&Collin, S. (2010). Les formations ouvertes à distance (FOAD) : Quelle contribution au développement de professionnels qualifiés en Afrique ? Questions Vives, 7(14), 71-87. 
Karsenti, T. \&Collin,S. (2011). Portrait of ODL in Africa: Results of a three-year longitudinal study (2007-2010). In S. Barton et al. (Eds.). Proceedings of Global Learn Asia Pacific (p. 19541958). AACE.

Karsenti, T. \& Collin, S. (2012). Using IT for Distance Learning: Benefits and Challenges for African Learners.Formation et Profession, 20(2), 9-18.

Karsenti, T. \& Collin, S. (2013). Distance Education in Africa: A Longitudinal Study of the Perceptions of 2,416 Students. International Journal of Technologies in Higher Education, 10(3), 76-90.

Karsenti, T.\&Tchameni Ngamo, S. (2009). Qu'est-ce que l'intégration pédagogique des TIC ? In T. Karsenti (dir.). Intégration pédagogique des TIC en Afrique : Stratégies d'action et pistes de réflexion (p. 57-75). Ottawa: CRDI.

Kinuthia, W. \& Stewart, M. (2010). Educational Technology in Practice: Research and Practical Case Studies from the Field. Charlotte, NC:Information Age Publishing.

Landry, P. (2003). Foad : Fresque historique. Distances et Savoirs, 1(3), 425-429.

Larose, F., Lenoir, Y., Karsenti, T.\&Grenon, V. (2002). Les facteurs sous-jacents au transfert des compétences informatiques construites par les futurs maîtres du primaire sur le plan de l'intervention éducative. Revue des Sciences de l'Éducation, 28(2), 265-287.

Lerbet, G. (1992). L'école du dedans. Paris: Hachette.

Lhomme, R.\&Fleury, J. (1999). Entretien avec Michel Callon. Recherche et Formation,31, 113-126.

Marty, O. (2014). Monetizing French Distance Education: A Field Enquiry on Higher Education Value(s). The International Review of Research in Open and Distance Learning, 15(2), 107-120.

Mbangwana, M.\&Ondoua, E. (2006). L'intégration pédagogique des TIC à l'école primaire publique au Cameroun. Fonkoua (dir.). Intégration des TIC dans le processus enseignement-apprentissage au Cameroun (p. 77-93). Yaoundé: Terroirs.

Millerand, F. (1998). Les usages des NTIC : Les approches de la diffusion, de l'innovation et de l'appropriation (1ère partie). COMMposite, 98(1), répéré le 12 avril 2010 du site. http://www.er. uqam.ca/nobel/r26641/uploads/images/Millerand\%2098\%20Usages\%201.pdf.

Moore, M. G. (2012). Handbook of distance education (2 nd London: Lawrence Erlbaum Associates.

Morin, P. (2003). Formation ouverte et à distance, vers la dimension économique: État des lieux et perspectives. Distances et Savoirs, 1(4), 551-565.

Onguéné Essono, L.- M.\&Onguéné Essono, C. (2006). TIC et Internet à l'école : Analyse des nouvelles pratiques enseignantes dans les salles de classe d'Afrique noire. In P. Fonkoua (dir.). Intégration des TIC dans le processus enseignement-apprentissage au Cameroun (p. 5575). Yaoundé: Terroirs.

Otto, T. L.\&Albion, P. R. (2002). Understanding the role of school leaders in realizing the potential of ICTs in education. Communication présentée au 13e colloque international de la Society for Information Technology and Teacher Education. SITE. Nashville, TE.

Rogers, E. M. (1995). Diffusion of Innovations. New York: The Free Press.

Rogers, E. M.\& Floyd, S. F. (1995). Communication of Innovation: A Cross-Cultural Approach. New York, N. Y: The Free Press.

Simonson, M., Smaldino, S., Albright, M. \& Zvacek, S. (2011). Teaching and learning at a distance: Foundations of distance education. New Jersey: Pearson Education.

Stewart, V. (2012). A World-Class Education: Learning from International Models of Excellence and Innovation. Alexandria, VA:ASCD.

Tchameni Ngamo, S. (2007). Stratégies organisationnelles d'intégration des TIC dans l'enseignement secondaire au Cameroun : Étude d'écoles pionnières (Thèse de Doctorat inédite). Département d'Andragogie et de Psychopédagogie, Université de Montréal, Montréal.

Tchameni, S.\&Karsenti, T. (2008). Intégration des TIC et typologie des usages: Perception des directeurs et enseignants des grandes écoles secondaires du Cameroun. Revue Africaine des Médias, 16(1), 45-72. 
Tchombé, T. M. S. (2006). Intégration of ICTs in Education in Cameroun. In P. Fonkoua (dir.). Intégration des TIC dans le processus enseignement-apprentissage au Cameroun (p. 11-53). Yaoundé : Terroirs.

Traoré, D. (2008). Quel avenir pour l'usage pédagogique des TIC en Afrique subsaharienne? Cas de cinq pays membres du ROCARE. In K. Touré, T.M.S. Tchombe et T. Karsenti (dir.). ICT and changing mindsets in Education. Bamenda, Cameroun: Langaa; Bamako, Mali: ERNWACA/ ROCARE.

Wallet, J. (dir.) (2007). Formation à distance en Afrique subsaharienne francophone. Paris: UNESCOBREDA.

Zaltman, G., Duncan, R.\& Holbek, J. (1973). Innovations and Organizations. Michigan: R.E. Krieger Publishing Company.

\section{AUTHOR'S BIOGRAPHY}

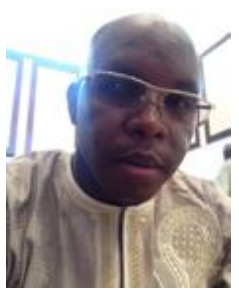

Dr. Emmanuel Béché, is currently conducting postdoctoral research at the University of Geneva on open and distance learning. He is Senior Lecturer in educational technologies at the University of Maroua, and Dean of online studies at IUDI.ORG. In 2014, he won the Price of the Best African emerging researcher in education, awarded by the Association for the Development of Education in Africa in partnership with the African Development Bank. In the same year, he was nominated for the Louis D'Hainaut Prize for the best Ph.D. dissertation in educational technologies, awarded by the Agence Universitaire de la Francophonie and the University of Mons. His research interests mainly concern the appropriation of technological innovations and instrumented devices at school. He recently co-edited a book on open and distance education in Cameroon. https://www.beche-emmanuel.com 